\title{
PERANAN PROYEKSI STITCH VIEW LONG LEG PADA PEMERIKSAAN KNEE JOINT DENGAN INDIKASI OSTEOARTHRITIS
}

\author{
Purwa Puspita Arum ${ }^{1}$ Panji Wibowo Nurcahyo ${ }^{2}$ \\ ${ }^{1}$ Laboratorium Klinik \& Rontgen Utama Purbalingga, Jawa Tengah, Indonesia \\ ${ }^{2}$ Poltekkes Kemenkes Semarang, Indonesia \\ Corresponding author: Purwa Puspita Arum \\ Email: purwapuspitaarum@gmail.com
}

\begin{abstract}
Introduction: Long Leg View is an x-ray examination of all parts of the lower extremity using a long vertical cassette which aims to measure the angle between the mechanical axis of the femur and tibia. Knee Joint examination with indications of osteoarthritis at the Radiology Installation of RSUP Dr. Sardjito Yogyakarta uses supine AP projection, Lateral recumbent, Skyline, and Stitch View Long Leg.

Methods: This research is a qualitative research with a case study approach. Collecting data by means of observation, documentation, and in-depth interviews with patients, sending doctors, radiologists, and radiographers. Data collection was carried out in March 2018 at the Radiology Installation of Dr. RSUP. Sardjito Yogyakarta. The data obtained were analyzed using an interactive model.

Results: On the Stitch View Long Leg examination at the Radiology Installation, Dr. Sardjito Yogyakarta uses a collimation area from the pelvis to the ankle joint. According to the resident doctor of orthopedic surgery and traumatology, Dr. Sardjito Yogyakarta, Stitch View Long Leg is able to see the shape of the foot formation, namely the $\mathrm{O}$ formation or $\mathrm{X}$ formation. In addition, according to radiology specialists, looking at the alignment deviation of the lower extremities can be used to assess the grade of osteoarthritis. Under normal conditions, the anatomical axis of the femur and tibia forms an angle of $6^{\circ} \pm 2^{\circ}$, while the mechanical axis line under normal conditions is $8 \mathrm{~mm} \pm 7$ $\mathrm{mm}$ medial to the center of the knee joint line. The alignment of varus and valgus has been associated with the development of medial or lateral osteoarthritis.

Conclusion: Stitch View Long Leg aims to assess the grade of osteoarthritis through assessment of lower extremity alignment deviations, see the overall mechanical and anatomical alignment of the lower extremities, help determine the calculation of the angle of bone cutting during Total Knee Replacement surgery, and see the right and left symmetrical balance of genu.
\end{abstract}

Keywords: Knee Joint Examination; Osteoarthritis; Stitch View Long Leg

\section{Pendahuluan}

Sendi lutut dibentuk oleh tiga persendian yaitu tibiofemoral joint, patellofemoral joint, dan proximal tibiofibular joint yang ditutupi oleh kapsul sendi (Syaifuddin, 2013). Sendi lutut merupakan sendi yang berfungsi sebagai pengatur pergerakan kaki. Pada bagian celah sendi lutut terdapat kartilago yang menutupi ujung-ujung tulang penyusun sendi dan cairan sinovial yang berperan sebagai pelumas yang membantu pergerakan antar dua buah tulang. Apabila cairan sinovial berkurang akan mengakibatkan lapisan kartilago menjadi kasar dan tipis dan menyebabkan penyempitan. Penyempitan ini disebut dengan osteoarthritis.

Osteoarthritis merupakan suatu penyakit sendi degeneratif dengan karakteristik berupa terjadinya kerusakan pada cartilage (tulang rawan sendi). Di
Indonesia, prevalensi osteoarthritis knee joint mencapai $5 \%$ pada usia $<40$ tahun, $30 \%$ pada usia 40-60 tahun, dan $65 \%$ pada usia $>61$ tahun dimana $15,5 \%$ diderita oleh pria dan $12,7 \%$ diderita oleh wanita (Dinkes, RI, 2007).

Menurut Bontrager (2018), proyeksi AP (Antero Posterior) Weight-Bearing bilateral dan proyeksi PA Weight-Bearing bilateral (Rosenberg Method)direkomendasikan untuk pemeriksaan knee joint pada kasus osteoarthritis. Di Instalasi Radiologi RSUP Dr. Sardjito Yogyakarta pemeriksaan knee joint dengan indikasi osteoarthritis dilakukan menggunakan proyeksi AP (Antero Posterior)dengan posisi pasien supine, proyeksi Lateral dengan posisi pasien recumbent, proyeksi Skyline dan proyeksiStitch View Long Leg. Long Leg View merupakan pemeriksaan dengan menggunakan sinar-x pada seluruh bagian 
ekstremitas bawah dengan menggunakan kaset vertikal panjang yang bertujuan untuk mengukur sudut antara sumbu mechanical axis antara tulang femur dan tibia (Zampogna, 2015).

\section{Metode}

Penelitian ini merupakan penelitian kualitatif dengan pendekatan studi kasus. Pengambilan data dengan cara observasi, dokumentasi, dan wawancara. Pengambilan data dilakukan pada bulan Maret 2019 di Instalasi Radiologi RSUP Dr. Sardjito Yogyakarta. Observasi dilakukan oleh peneliti dengan cara mengamati secara langsung prosedur pemeriksaan knee joint dengan indikasi osteoarthritis. Data dokumentasi, peneliti memperoleh data yang diambil dari surat permintaan foto rontgen, hasil foto radiograf, dan hasil bacaan yang berkaitan dengan pemeriksaan osteoarthritis. Wawancara mendalam dengan pasien, dokter pengirim, dokter spesialis radiologi, dan radiografer masing-masing berjumlah 1 orang.

Data yang diperoleh dianalisis dengan menggunakan interaktif model dengan tahap pengumpulan data, reduksi data, penyajian data dan pengambilan kesimpulan.

\section{Hasil Dan Pembahasan \\ Riwayat Pasien}

Berdasarkan hasil wawancara diperoleh data bahwa pasien mengeluh sakit pada kaki bagian kiri terutama lututnya. Pasien pernah mengalami kecelakaan akibat terpeleset menghindari bis pada tahun 2002 dan membuat kaki kiri pasien bengkok. Pada tanggal 6 Februari 2019, pasien dikirim olehsalah satu dokter residen orthopedi dari Poli Bedah Orthopaedi \& Traumatologi untuk dilakukan pemeriksaan radiografi knee joint dengan diagnosis/DD OA gепи $S$.

Pemeriksaan Knee Joint Indikasi Osteoarthritis

Berdasarkan observasi yang telah dilakukan, pemeriksaan knee joint dengan indikasi osteoarthritis di Instalasi Radiologi RSUP Dr. Sardjito Yogyakarta tidak memerlukan persiapan khusus. Sebelum pemeriksaan radiografer menjelaskan tentang prosedur pemeriksaan yang akan dilakukan, kemudian pasien disuruh untuk mengganti baju yang dikenakannya dengan baju pasien yang telah disiapkan. Setelah itu pasien diminta untuk berbaring di atas meja pemeriksaan.

Berdasarkan observasi yang telah dilakukan, persiapan alat antara lain pesawat sinar X merk Philips tipe Digital Diagnostic Class I-Type B, Image Detector ukuran 35 x $43 \mathrm{~cm}$, DR Unit dan Film Printer. Komputer DR sebagai control programdan pengolah gambar.

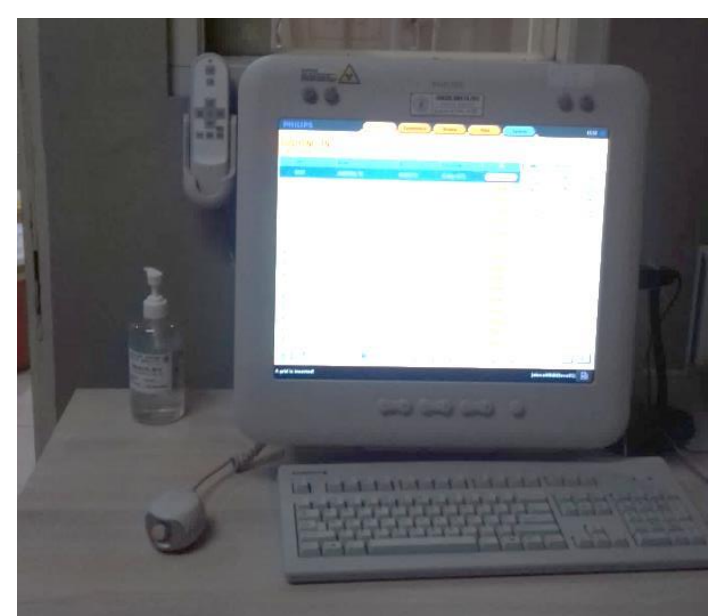

Komputer DR di Instalasi Radiologi RSUP Dr. Sardjito Yogyakarta

Berdasarkan observasi yang telah dilakukan, pemeriksaan knee joint dengan indikasi osteoarthritis di Instalasi Radiologi RSUP Dr. Sardjito Yogyakarta menggunakan proyeksi AP supine, Lateral recumbent, Skyline, dan Stitch View Long Leg. Tujuan dilakukannya pemeriksaan knee joint dengan indikasi osteoarthiritis di Instalasi Radiologi RSUP Dr. Sardjito Yogyakarta adalah untuk menentukan diagnosis, menentukan grading osteoarthritis, dan untuk menentukan terapi baik berupa operasi atau pengobatan conservative. Tujuan lainnya adalah untuk melihat adanya penyempitan, adanya defek pada tulang, melihat osteofit, menentukan grade, adanyasklerotik enplit pada kartilago, adanya kemungkinan subluksasi, dan kemungkinan adanyafussion antar tulang.

\section{Proyeksi Stitch View Long Leg}

Pada proyeksi ini, posisi pasien erect di depan bucky stand. Posisi objek dengan memposisikan pasien dengan mengatur bagian dari ekstremitas bawah pasien yaitu mulai dari hip joint hingga ankle joint pasien lurus dan true AP serta berada pada pertengahan bucky stand. Sinar diarahkan horisontal tegak lurus pada pertengahan detector. Titik bidik diatur pada pertengahan dari ekstremitas bawah yaitu antara knee joint dan femur bagian distal. Sinar diarahkan horisontal tegak lurus pada pertengahan bucky stand/detektor. Focus Film Distance diatur sebesar $200 \mathrm{~cm}$. Faktor eksposi adalah $85 \mathrm{kVp}$ dengan $15 \mathrm{mAs}$.

Kemudian pada sistem komputer, dipilih menu DR Long Leg Both Peds yang merupakan menu atau program yang telah diatur untuk pemeriksaan Stitch view long leg. Pada saat eksposi berlangsung, melalui sistem pada komputer DR, area atau titik bidik akan mulai mengekspose dalam 3 bagian yaitu area atas dari pelvis hingga femur bagian proximal, area tengah dari body of 
femur hingga knee joint, dan area bawah dari distal of knee hingga ankle joint. Kemudian ketiga area tersebut akan digabungkan secara otomatis oleh sistem komputer DR yang disebut dengan istilah stitching.

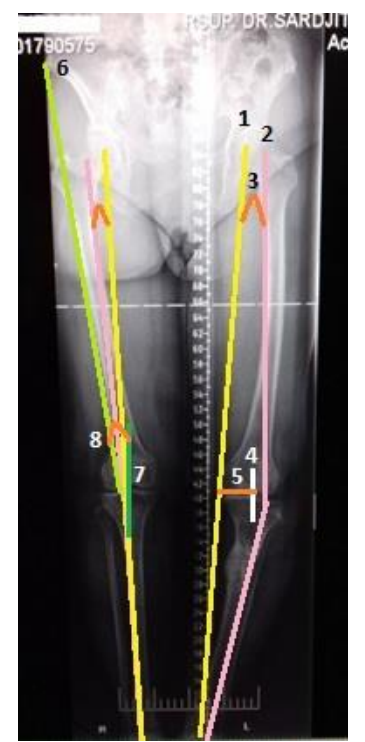

Hasil radiograf Stitch View Long Leg

Keterangan gambar :

1. Garis Mechanical Axis Lower Extremity

2. Garis Anatomical Axis Lower Extremity

3. Sudut Anatomical Axis

4. Center of Knee Joint

5. Jarak penyimpangan garis Mechanical Axis

6. Garis dari SIAS menuju ke center of patella

7. Garis dari center of patella menuju ke tibial tubercle

8. Q-angle (Quadriceps angle)

Stitch View Long Leg bertujuan untuk melihat keseluruhan alignment ekstremitas bawah, untuk mengukur alignment tulang secara mekanik dan anatomik, kemudian untuk membantu menentukan perhitungan sudut untuk pemotongan tulang saat operasi Total Knee Replacement atau ganti sendi lutut, untuk melihat keseimbangan simetrical kanan kiri dari genu, dan untuk melihat bentuk formasi kaki yaitu formasi O atau formasi X. Dari melihat keseluruhan alignment ekstremitas bawah, dokter radiolog juga dapat menilai grade dari osteoarthritis itu sendiri.

Menurut Hunter (2017) melalui Long Leg View akan memperlihatkan ada tidaknya malalignment yang merupakan akibat dari penyimpangan pada garis mechanical axis yaitu garis yang ditarik pada radiografi anteroposterior kaki saat berdiri, dari pusat caput femoral ke pusat "dome" talar serta sumbu anatomical axis yaitu sudut yang dibentuk oleh perpotongan garis yang berasal dari pusat lutut ke atas menuju pusat shaft femur dan garis ke bawah dari pusat lutut menuju ke pusat shaft tibia. Penyimpangan dari garis dan sumbu ini dapat mengakibatkan kelainan atau deformitas yang disebut dengan varus dan valgus.

\section{Kesimpulan}

Stitch View Long Legbertujuan untuk melihat keseluruhan alignment ekstremitas bawah secara mekanik dan anatomik, membantu menentukan perhitungan sudut pada pemotongan tulang saat operasi Total Knee Replacement, melihat keseimbangan simetrical kanan kiri genu dan bentuk formasi kaki serta untuk menilai grade dari osteoarthritis melalui penilaian pada penyimpangan alignment ekstremitas bawah.

\section{Daftar Pustaka}

Bontrager, K. L. MA.RT . LRJ. 2018. Textbook of Positioning and Related Anatomy, Ninth Edition. St. Louis: CV. Mosby Company.

Dinkes RI, (2007). Riset Kesehatan Dasar (Rikesdas). Jakarta : Badan Penelitian dan Pengembangan Kesehatan Departemen Kesehatan Republik Indonesia.

Hunter, Niu, Felson, Harvey, Gross, McCree, Aliabadi, Sack, Zhang. 2007. Knee Alignments Does Not Predict Incidents Osteoarthritis: The Framingham Osteoarthritis Study. 56(4):1212-8. Journal of Arthritis Rheumatoid. https://www/ncbi.nlm.nih.gov/pubmed/173 93450 . Diakses pada pukul 07.08 WIB. Kamis, 17 Januari 2019.

Syaifuddin, H. 2013. Anatomi Fisiologi Kurikulum Berbasis Kompetensi Untuk Keperawatan dan Kebidanan. Jakarta: EGC

Zampogna, B., Vasta S., Amendola, A., Marbach, B., Gao, Y., Papalia, R., Denaro, V. 2015. Assesing Lower Limb Alignment : Comparison of Standar Knee Xray vs Long Leg View. The Iowa Orthopaedic Journal. https://www.ncbi.nlm.nih.gov/pmc/articles /PMC4492139/ Diakses pada pukul 10.36 WIB. Selasa, 29 Januari 2019. 